\title{
Civilian Morale During the Second World War: Responses to Air Raids Re-examined
}

\author{
By EDGAR JONES ${ }^{\mathrm{a}}$, ROBIN WOOLVEN ${ }^{\mathrm{b}}$, BILL DURODIÉc ${ }^{\mathrm{c}}$, and SIMON \\ WESSELY ${ }^{\text {d }}$
}

\begin{abstract}
SUMMARY. The impact of air raids on civilian morale during the Second World War has been the subject of much dispute. Official histories concluded that the mental health of the nation may have improved, while panic was a rare phenomenon. Revisionist historians argued that psychiatric casualties were significantly higher than these accounts suggested because cases went unreported, while others were treated as organic disorders. Using contemporary assessments and medical literature, we sought to re-evaluate the psychological effect of bombing. There is little evidence to suggest that admissions for formal mental illness increased appreciably, although a question remains about the incidence of functional somatic disorders, such as non-ulcer dyspepsia and effort syndrome. The fact that civilians had little to gain from hospitalization in part explained why dire predictions of mass air-raid neurosis failed to materialize. In the event, civilians proved more resilient than planners had predicted, largely because they had underestimated their adaptability and resourcefulness, and because the lengthy conflict had involved so many in constructive participant roles.
\end{abstract}

KEYWORDS: psychological casualties, air raids, traumatic neurosis, the Blitz, panic, conversion disorders, somatization, morale.

In the aftermath of 11 September and the war against Iraq, the threat of terrorist attack has become very real. How civilians might respond to a major offensive remains an open question but one which may reflect the morale and behaviour of people exposed to air raids, as was the case during the Second World War. The official interpretation, published in the post-war period, was framed by Titmuss, who argued in Problems of Social Policy that not only was morale sustained throughout the war, but that there was also no panic and no rush to safety. ${ }^{1}$ Furthermore, he claimed that the mental health of the nation improved, attributable to a universal will to work under the stress of national necessity. Key factors identified by Titmuss in maintaining morale at high levels included:

leadership, an equitable sharing-out of food, shelter and social services, a job to do in a stable economy, and the provision of safety-valves ranging from voluntary evacuation schemes to various mechanisms whereby public opinion could be effectively expressed .... The individual's responsibility to his family, whose respect he valued, was thus encouraged to develop its maximum strength. ${ }^{2}$

\footnotetext{
${ }^{a}$ Department of Psychological Medicine, Guy's, King's, and St Thomas' School of Medicine, 103 Denmark Hill, London SE5 8AZ, UK. E-mail: E.Jones@hogarth7.demon.co.uk

${ }^{\mathrm{b}}$ Centre for Defence Studies, Department of War Studies, King's College London, The Strand, London WC2R 2LS, UK. E-mail: Robin.Woolven@btopenworld.com

${ }^{c}$ International Centre for Security Analysis, Department of War Studies, King's College London, The Strand, London WC2R 2LS, UK. E-mail: bill.durodie@kcl.ac.uk

${ }^{\mathrm{d}}$ Institute of Psychiatry, Weston Education Centre, 10 Cutcombe Road, London SE5 9RJ, UK. E-mail: s.wessely@iop.kcl.ac.uk

${ }_{1}^{1}$ R. M. Titmuss, Problems of Social Policy (London, 1950), p. 343.

${ }^{2}$ Ibid., p. 348.
} 
In his study of Civil Defence, O'Brien took an equally sanguine view of morale. Writing of the Blitz in autumn 1940, he argued,

the phrase 'London can take it' became current, and there is small doubt that this reflected the reality of the situation .... Evacuation ... was relatively small, and there was no panic. ${ }^{3}$

Drawing a distinction between 'passive' morale (a grim willingness to carry on) and 'active' morale (heroic gestures), Marwick detected no fundamental weakening of resolve throughout the war. ${ }^{4}$

Questioning these optimistic interpretations, Calder suggested that panic and defeatism after major raids, looting of bombed premises, black marketeering, strikes, juvenile delinquency, and higher rates of infantile mortality all indicated that civilian morale was not uniformly robust. ${ }^{5}$ In a later study, Calder argued that Britain in 1940 provided 'ample evidence, familiar and unfamiliar, to indicate widespread fear and paranoia bordering on panic'. ${ }^{6}$ Similarly, Ponting maintained that sustained morale during the Blitz owed more to government propaganda and a censored media than to reality. ${ }^{7}$ In his study of the devastating raids on Belfast in April and May 1941, Barton concluded that inadequate preparations and the destruction of 53 per cent of the entire housing stock led to mass evacuations, which assumed panic proportions. ${ }^{8}$ By contrast, Ziegler, who limited his study to London, conceded that the fighting spirit faltered at times, but concluded that the majority behaved with 'dignity, courage, resolution and astonishing good humour'. However, a recent investigation of civilian morale during 1940 by Smith returned to a position closer to that of Titmuss and O'Brien, ${ }^{10}$ while Mackay's general investigation of the war years concluded that:

The 'negative' features emphasised by revisionist historians, although indisputably present, were not on such a scale as to invalidate the orthodox picture of a people who became actively committed to the project their leaders put before them . . . the 'lows' did not last for long and were more than outweighed by the 'highs'. ${ }^{11}$

Civilian morale was, of course, not simply a response to air raids but to a range of factors, such as the availability of food, the cost of living, news about progress in the war, and the provision of health and welfare benefits. Within the scope of this article, we were unable to assess all of these influences, and focused on the psychological impact of bombing. Received opinion is that there was no public panic, except in isolated incidents such as the Bethnal Green tube disaster, and that the incidence of psychiatric disorders among civilians did not increase to any significant extent even in areas subjected to heavy attacks, such as the East End of London, Liverpool, or Southampton. Psychiatric admissions following raids, it was claimed, were of individuals with a pre-existing disorder or constitutional vulner-

${ }^{3}$ T. H. O’Brien, Civil Defence (London, 1955), p. 401.

${ }^{4}$ A. Marwick, The Home Front, The British and the Second World War (London, 1976), pp. 68-71.

${ }^{5}$ A. Calder, The People's War: Britain 1939-45 (London, 1969).

${ }^{6}$ A. Calder, The Myth of the Blitz (London, 1991), p. 109.

${ }^{7}$ C. Ponting, 1940: Myth and Reality (London, 1990).

${ }^{8}$ B. Barton, The Blitz: Belfast in the War Years (Belfast, 1989).

${ }^{9}$ P. Ziegler, London at War 1939-45 (London, 1995).

${ }^{10}$ M. Smith, Britain and 1940: History, Myth and Popular Memory (London, 2000).

${ }^{11}$ R. Mackay, Half the Battle, Civilian Morale in Britain during the Second World War (Manchester, 2002), p. 248. 
ability. We sought to re-examine this interpretation. Were people as resilient, adaptable, and impervious to the stress of air raids as official histories have claimed? If people did break down, what had caused this to happen and, for those who survived apparently unscathed, what were the preventive factors?

\section{Definitions and Methods}

To analyse contemporary assessments of morale, we systematically searched all files of the Home Intelligence Division of the Ministry of Information and the intelligence branch of the Ministry of Home Security. A keyword search was performed using PROCAT for the records of other relevant departments such as the War Office, Prime Minister's Office, Cabinet Office, and the Air Ministry. In addition, leading medical journals of the period were hand-searched for papers that studied psychological disorders in civilians subjected to air attack.

Morale can be conceptualized in a variety of ways, and for the purpose of this study we adopted the definition employed by Dr Stephen Taylor, a physician, who had trained at the Maudsley Hospital. As director of the Home Intelligence Division of the Ministry of Information, he wrote in October 1941: 'Morale [should be defined] not by what a person thinks or says, but by what he does and how he does it'; it was 'the state of conduct and behaviour of an individual or group'. ${ }^{12}$ MacCurdy reiterated this interpretation in 1943, stating that an attitude of resilience was 'meaningless, or at least ineffective, unless it promotes action'. ${ }^{13}$

\section{Preparation for Aerial Bombing}

When, in 1932, Stanley Baldwin declared in the House of Commons that "no power on earth can prevent the man in the street from being bombed . . . the bomber will always get through', he was expressing a view supported by the Air Staff. ${ }^{14}$ Military planners believed that a 'knock-out blow' could be delivered from the skies by wiping out a substantial section of the urban population. By scaling-up casualty statistics derived from German air raids on London in 1917-18, the Committee of Imperial Defence (CID) calculated in 1937 that a 60-day offensive could kill as many as 600,000 and leave 1.2 million injured. ${ }^{15}$ These frightening numbers took on an even more sinister aspect when related to earlier predictions about the psychological effects of bombing on civilians.

Concerned by civilian responses during the First World War, in 1924 the government set up an Air-Raid Precautions Sub-Committee of the CID. One of its earliest pronouncements that 'the moral effect of air attack is out of all proportion to the material effect' was to exercise a profound and enduring influence. ${ }^{16}$ This theme was developed by Sir Maurice Hankey, secretary of the CID, who

\footnotetext{
12 The National Archives, Public Record Office, Kew (hereafter PRO), INF1/292, Ministry of Information Weekly Reports, No. 53, 8 October 1941, S. Taylor, 'Home morale and public opinion', p. 1.

${ }^{13} \mathrm{~J}$. T. MacCurdy, The Structure of Morale (Cambridge, 1943), pp. 72, 141.

${ }_{14}$ R. Woolven, 'Munich, London and ARP', RUSI Journal, 143 (1998), 54-8, p. 54.

15 Titmuss, Social Policy, p. 13.

${ }^{16}$ PRO, CAB46/1, Meeting 23 June 1924.
} 
argued that victory in any future war 'will rest with that country whose people will endure bombardment the longer with greater stoicism'. He questioned the preparedness of the general public "who have no realisation what is in store in the event of another war on a large scale, and I am apprehensive that the full realisation would come as so great a shock that general panic would ensue'. ${ }^{17}$ Reports of large numbers seeking shelter in Underground stations in response to the German air raids of 1917-18 appeared to provide the Committee with further evidence that civilians lacked the resilience needed to survive a concerted air attack. ${ }^{18}$ As a result, the primary aim of ARP services, as defined in June 1937, was not the protection of individuals and property from destruction, but 'the maintenance of the morale of the people'. ${ }^{19}$ Plans were laid for some 17,000 regular troops and 20,000 reserve constables to be drafted into London to control the expected mass exodus from the capital and to prevent panic at main-line stations and entrances to the Underground.

Fear of widespread psychological breakdown also influenced the levels of protection offered to citizens. A deep-shelter system, the only effective defence against bombs, was rejected not simply because it was costly to construct. Planners believed that it might create a 'shelter mentality' and that essential war production would suffer as workers became increasingly reluctant to emerge from positions of safety. ${ }^{20}$ The system was also rejected on grounds of equality, as the Hailey Conference of February 1939 had decided that morale could be maintained only if the same standards of protection were applied across areas of equivalent risk. Concerns about a deep-shelter mentality endured and, in 1942, when eight new shelters (each accommodating 8,000 people) were completed beneath Underground stations, they were retained for military use; not until the V1 offensive of 1944 were five opened to the public. ${ }^{21}$

\section{Air Raids in Spain and China}

Although it had been predicted that for every physical casualty there would be two to three psychological, these estimates were not supported by events of the late 1930s. Reports from British military observers of the Sino-Japanese hostilities suggested that 'there was good discipline and control' when Nanking was attacked in August 1937. While high officials went to their dugouts, 'the masses were apathetic to air-raids'. ${ }^{22}$ A year later, Wing Commander Pelly, the air attaché in Shanghai, observed that Japanese raids had stiffened Chinese resilience despite often 'heavy and indiscriminate bombing' of large centres of population. Pelly's evidence was supported by a German journalist based in Hankow, who wrote that

\footnotetext{
${ }^{17}$ PRO, CAB46/3 ARP/8, Memorandum by Sir Maurice Hankey, 2 July 1924.

${ }^{18}$ O'Brien, Civil Defence, p. 6; H. A. Jones, War in the Air, Being the Story of thePart Played in the Great War by the Royal Air Force, Volume 5 (London, 1935), p. 136.

${ }^{19} \mathrm{PRO}, \mathrm{CAB} 16 / 172$, Minutes and report of the Warren Fisher Sub-committee of the CID on ARP Services, 30 June 1937.

${ }^{20}$ O'Brien, Civil Defence, p. 192.

${ }^{21} \mathrm{R}$. Woolven, 'London and the V Weapons 1943-45', RUSI Journal, 147 (2002), 53-9, p. 54.

22 PRO, ADM116/4174, Reports from HMS Capetown on Japanese raids on Nanking from 2 August 1937.
} 
the Japanese air offensive had been 'materially incapable of affecting the will to resist on the front or hinterland or of producing panic . . . even when continued for weeks . . . it merely produces a strong feeling of hatred, which indirectly strengthens the defences'. ${ }^{23}$ Although these reports reached the Air Ministry, they were discounted, probably because planners agreed with Pelly's view that the observed resilience was a racial characteristic: 'the Chinese are more fatalistic and possibly less imaginative than the Western races' ${ }^{24}$

Evidence from the Spanish Civil War, published in the British Medical Journal, also had little immediate influence on policy. Emilio Mira, professor of psychiatry at Barcelona University, demonstrated that the incidence of psychiatric disorders in the city did not rise significantly as a result of air raids. ${ }^{25}$ 'After a time', Mira argued:

the people in the city became almost indifferent to the bombardment if it did not affect their own district . . . It should, however, be emphasised that the great part of the population would feel what may be called 'normal anxiety' during an air raid, but never need psychiatric attention. ${ }^{26}$

Although the Air Ministry and CID had reached pessimistic conclusions about the psychological responses of civilians to air raids, the UK medical profession was less decided. Some, such as W. R. Bion and Hugh Crichton-Miller, believed that it was impossible to predict the effect. ${ }^{27}$ John Rickman argued that 'the strain of war conditions in the direction of disturbing morale will affect a small proportion of civilian population seriously and a larger proportion subliminally'. ${ }^{28}$ Wright believed that morale would be determined by 'class, to a greater extent on the density of the population exposed, and probably to the greatest extent on the adequacy of the protective measures and the confidence these measures inspire' ${ }^{29}$ Denied the training and group protection afforded to soldiers, Crichton-Miller and Hargreaves considered that civilians could more readily succumb to a powerful desire for self-protection, regressing to a state of infantile dependency. ${ }^{30}$

Planners, advised by two veterans of the First World War (Gordon Holmes, a neurologist, and Bernard Hart, a psychiatrist), took a pessimistic view of civilian responses and opened specialist hospitals (termed 'Neurosis Centres') in the outskirts of major cities to treat the expected epidemic of psychiatric casualties. ${ }^{31}$ In London, the staff of the Maudsley were despatched either to Belmont Hospital in

${ }^{23}$ PRO, WO106/5296, Experiences of a German journalist in Hankow, 17 September 1938.

${ }^{24}$ PRO, AIR2/3558, Air Operations during Sino-Japanese Hostilities, November 1938.

${ }^{25}$ E. Mira, 'Psychiatric Experience in the Spanish War', British Medical Journal, 1 (1939), 1217-20, p. 1217.

${ }^{26}$ Ibid., p. 1218.

${ }^{27}$ G. R. Hargreaves, 'Psychological Casualties in War', British Medical Journal, 2 (1939), 1161; H. Crichton-Miller, 'Neuroses in War-time', British Medical Journal, 1 (1939), 169-70, p. 169.

${ }^{28} \mathrm{~J}$. Rickman, 'The Mental Aspects of ARP', British Medical Journal, 2 (1939), 457-8, p. 458.

${ }^{29}$ M. B. Wright, 'Psychological Emergencies in War-time', British Medical Journal, 2 (1939), 576-8, p. 576.

${ }^{30}$ W. R. Bion, 'The "War of Nerves": Civilian Reaction, Morale, and Prophylaxis', and H.CrichtonMiller 'General Conclusion', in E. Miller (ed.), The Neuroses in War (London, 1940), 180-200, pp. 178-9, 184-5, 201-10, pp. 202-3.

${ }^{31}$ A. B. Stokes, 'War Strains and Mental Health', Journal of Nervous and Mental Disease, 101 (1945), 215-19. 
Sutton, or to the converted premises of Mill Hill public school. ${ }^{32}$ During the First World War, it had been shown that the further a shell-shocked soldier was evacuated from the trenches, the less likely it was that he would recover. As a result, hospitals were set up in locations of comparative safety but within the sound of bombs to encourage patients to return to work in danger zones. When the expected civilian casualties failed to materialize, these units were diverted to military uses.

\section{Early Assessments of Morale: Ministry of Home Security}

From August 1940, regular weekly morale reports were prepared by the intelligence branch of the Ministry of Home Security. ${ }^{33}$ Although filled with telling anecdotal evidence, their value as objective evaluations of civilian resilience was undermined by the intrusion of the authors' prejudices. R. H. Parker, director of the Home Publicity Division, was responsible for most of the reports written during 1940. Known as 'judge' Parker because of his earlier legal career in India, he had a penchant for lengthy memoranda in an up-beat patriotic style. ${ }^{34}$ Sources were not revealed, while the assessments themselves read like morale-boosting propaganda. At the height of the Blitz, for example, Parker recorded that 'there is little appearance of nervous or physical overstrain ... . Nothing has affected the unconquerable optimism of the Cockney, nor has anything restricted his ready, if graveyard, humour'. ${ }^{35}$

In addition, the Ministry of Home Security received reports from various local sources, including the police and Civil Defence officials. In autumn 1940, an analysis of 50 confidential assessments by chief constables led to the satisfying conclusion that 'it is notable that in no single instance is there any suggestion of the least faltering in the public courage'. ${ }^{36}$ The report from Lancashire was typical: 'in an area which had been bombed for several successive days, the opinion was expressed that people could not stand the strain for long but this feeling has gradually subsided, and the presence of our fighter aircraft patrolling in the vicinity has increased public confidence'. In July 1940, the Civil Defence Commissioner based in Reading and responsible for the Southern Region concluded that:

The present state of morale is very high. The weak spots are in the middle rather than the working class .... There is some suspicion that the well-to-do are privileged, and that there is tolerance for defeatism among them. The raids have been met with courage and a remarkable degree of indifference. ${ }^{37}$

\footnotetext{
${ }^{32}$ E. Jones, 'Aubrey Lewis, Edward Mapother and the Maudsley', Medical History, Supplement 22 (2003), 3-38, pp. 28-9.

${ }^{33}$ PRO, HO199/444, Weekly Morale Reports prepared by the Intelligence Branch, 27 August 1940.

${ }^{34}$ I. McLaine, Ministry of Morale: Home Front Morale and the Ministry of Information in World War Two (London, 1979), p. 199.

${ }^{35}$ PRO, HO199/444, Weekly Morale Report, 7 October 1940, p. 1.

${ }^{36}$ PRO, HO199/316, Morale of the Public during and after Air-raids, Extracts from Chief Constables' Reports.

${ }^{37}$ PRO, HO199/410, Policy regarding Monthly Reports on Morale received from Regional Commissioners, Monthly Report, Region 6, two months ended 13 July 1940.
} 
The Ministry of Home Security believed that the "chain of personal contacts which exists between regional headquarters and the vast network of ARP personnel' provided them with a 'digest of whose findings might safely be considered as representative or indeed universal'. ${ }^{38}$ But, how robust was the evidence gathered from these reports? They often relied on the subjective assessment of one individual, who was plausibly biased against including accounts of low morale as they would imply that he was himself inefficient or simply defeatist. These reports, prepared by apparently well-informed officials, illustrated how, in the absence of a rigorous methodology, it was possible to succumb to institutional bias.

\section{Ministry of Information}

The newly-created Ministry of Information, staffed by journalists, broadcasters, academics, and lawyers, had a relatively low proportion of career civil servants and developed a relatively liberal and broadly-based culture. ${ }^{39}$ The daily reports on home morale, prepared by its Home Intelligence Division, were a synthesis of various sources and less inhibited than those from the Ministry of Home Security. During 1940, they supported the impression that resilience was not universal or unfaltering. The Blitz on London was described as causing 'considerable apprehension', while 'East-Enders experiencing screaming bomb[s] for the first time expressed great fear but did not panic'. ${ }^{40}$ However, others did lose control during alerts:

Confusion reported in Piccadilly after crowd had made for large Swan \& Edgar's shelter to find it was closed on Sundays. Elderly people started panicking and it took several minutes for policemen to disperse crowds to other shelters. ${ }^{41}$

Reactions to raids in London varied widely: 'four people in one Kensington bus panicked at a siren; other reports show many people running to shelters and then leaving them before the All Clear sounded'. Although confidence was 'still strong', by September 1940, 'terror stories' were said to be 'frequent', accompanied by rumours of new weapons, and 'evidence that physical tiredness is beginning to have an effect on nerves'. ${ }^{42}$ The challenge facing the government was to determine which of these conflicting accounts were representative.

\section{Mass-Observation Reports}

The answer appeared to lie in the Mass-Observation reports presented to the Admiralty in December 1940 and January 1941 on the effect of raids on Coventry, Bristol, Cheltenham, Southampton, Manchester, and Liverpool. ${ }^{43}$ Mass-Observation, a pioneer opinion-measuring organization, had been founded in 1937 by Tom

${ }^{38}$ Ibid., Memorandum from Intelligence Branch, 20 May 1940.

${ }^{39}$ McLaine, Ministry of Morale, pp. 277-8.

${ }^{40}$ PRO, INF1/264 Daily Report on Morale, 30 August 1940, London, 26 August 1940.

${ }^{41}$ Ibid., London, 19 August 1940.

${ }^{42}$ Ibid., Daily Observations, 19 September 1940, 21 September 1940.

${ }^{43}$ PRO, HO199/442, Reports of the Mass-Observation Group, Morale of Naval Ratings, Dockyard Personnel and Public. 
Harrisson (1911-76), an anthropologist, Charles Madge, a poet and journalist, and Humphrey Jennings, a documentary film maker. ${ }^{44}$ With a nationwide panel of 1,500 voluntary observers and two groups of full-time staff in Fulham and Bolton, it achieved prominence for its studies of daily life and the attitudes of working people. ${ }^{45}$ However, the bias of their investigators and the nature of their interviews were not disclosed. Mass-Observation was politically left-of-centre and reformist in outlook. While recognizing their expertise, Richard Crossman argued that its staff were 'inclined to turn a hint into a scientifically demonstrated fact' and that there was 'a considerable element of subjectivity in the results obtained' ${ }^{46}$

The intense and destructive raid of 14-15 November 1940 on Coventry, according to Mass-Observation investigators, led to:

an unprecedented dislocation and depression ... . There were more open signs of hysteria, terror, neurosis observed in one evening than during the whole past two months together in all areas. Women were seen to cry, scream, to tremble all over, to faint in the street, to attack firemen. The overwhelming dominant feeling on Friday was the feeling of utter helplessness .... In two cases people were seen fighting to get on to cars, which they thought would take them out into the country, though, in fact, as the drivers insisted, the cars were just going up the road to garage. ${ }^{47}$

Although a quiet night, followed by a fine morning, 'changed the atmosphere for the better', it was predicted that another intense raid would have produced 'more striking and terrible' results. What could have explained the panic in Coventry? First, the intensity of the destruction was unprecedented. 'The very compact and crowded nature of the town', the investigators concluded, 'made the damage dominate the whole scene ... [and] made the shock effect much greater per bomb'. Secondly, Coventry had not experienced a period of 'hardening'. ${ }^{48}$ In Liverpool, by contrast, where the population had been prepared by a series of lighter air raids, the impact of a major assault was lessened and morale remained high. ${ }^{49}$ Indeed, a study by Vernon, based on interviews with psychologists and psychiatrists who had treated air-raid casualties, suggested that 'people generally find a continued succession of raids less trying than sporadic ones since they become disadapted [sic] during the quiet intervals'. ${ }^{0}$

Comparative studies of Southampton, Bristol, Liverpool, and Manchester suggested that morale did not simply fluctuate in direct relationship to the tonnage of bombs dropped. ${ }^{51}$ Bristol, which had suffered far less damage than either Coventry or Southampton, was reported as having low morale, the main complaint being a

${ }^{44}$ Mackay, Half the Battle, pp. 10-11.

${ }^{45}$ N. Longmate, Air Raid, The Bombing of Coventry (London, 1976), pp. 212-14.

${ }^{46}$ PRO, INF1/261, R. H. S. Crossman, Report on the Work of Mass-Observation', 26 October 1939 , p. 1.

${ }_{47}^{4}$ PRO, HO199/442, Report on Coventry by the Mass Observation Group, 18 November 1940, p. 2.

${ }^{48}$ T. Harrisson, Living through the Blitz (London, 1976), p. 135.

${ }^{49}$ PRO, HO199/442, Report on Liverpool and Manchester, 10 January 1941, p. 4.

${ }^{50}$ P. E. Vernon, 'Psychological Effects of Air-Raids', Journal of Abnormal and Social Psychology, 36 (1941), 457-76.

${ }^{51}$ D. Thoms, 'The Blitz, Civilian Morale and Regionalism, 1940-42', in P. Kirkham and D. Thoms (eds), War Culture: Social Change and Changing Experience in World War Two (London, 1995), 3-12. 
dissatisfaction with the shelters, which was judged 'spontaneous, non-political and actually justified'. Despite heavy raids, morale in Liverpool remained consistently high. ${ }^{52}$ The damage had not been concentrated and the city centre, its psychological heart, had survived quite well, enabling repairs to essential services to be effected relatively swiftly. It was also thought that the harsh pre-war economic conditions, with high unemployment and men often away at sea, had toughened the population.

By contrast, raids on Manchester over 22-26 December 1940 had a significant impact:

While plenty of people in Manchester were determined and courageous, and few openly defeatist, careful analytical discussions with sample people . . . pointed to a considerable private opinion of real depression and despair. Manchester people are definitely on edge, are afraid of the next raid, are beginning to really worry about the future. ${ }^{53}$

Rumour was said to be widespread, talk about air raids was common, and alarm openly visible when sirens sounded, and considerable evacuation from the city was described. All were identified as signs of low morale. Like Coventry, Manchester had suffered from concentrated raids without a period of conditioning. The utility services and transport system were severely affected. Little had been done in terms of public broadcasts and information to raise morale and, over the Christmas period, the people of Manchester believed that they had been neglected. Practical organization for the homeless appeared wanting. 'The morale of the bombed', the observers concluded, 'largely depends on the care they get in the first 36 hours' ${ }^{4}$ which in practice related to the quality of the rest centres, facilities for children, information provided, health care, and provision of food.

\section{Ministry of Home Security: Research and Experiments Department}

Stung by the Mass-Observation reports, which were more incisive than anything they had produced, the Ministry of Home Security directed its Research and Experiments Department to investigate the impact of air raids on morale and productive output. ${ }^{55}$ Professors J. D. Bernal and Solly Zuckerman compared the effects of raids on Birmingham and Hull. They found that the former possessed 'an inner buoyancy . . . while Hull was . . torpid and apathetic' ${ }^{56}$ Because of the city's very size, and growing industries, production in Birmingham fell by less than 5 per cent. Stable employment and high wages also deterred people from widespread evacuation or trekking at night. Hull, by contrast, experienced an economic depression following the loss of trade with Scandinavia and the Low Countries. Although 10,000 people left Birmingham every month as a result of raids, they

\footnotetext{
${ }^{52}$ B. Beaven and D. Thoms, 'The Blitz and Civilian Morale in Three Northern Cities', Northern History, 32 (1996), 195-203.

${ }^{53}$ PRO, HO199/442, Report on Liverpool and Manchester, 10 January 1941, p. 9.

${ }^{54}$ vIbid., p. 11.

${ }^{55}$ PRO, HO199/453, 'Ministry of Home Security Research and Experiments Department, Social and Economic Study of the Effects of Air-Raids on Towns, 29 September 1941.

${ }^{56}$ PRO, HO199/453, Total Effects of Air-Raids (Ministry of Home Security Report 2770), Air Ministry (Air Liaison) Commentary, 5 May 1942, p. 3.
} 
were immediately replaced by similar numbers attracted by the ready availability of well-paid jobs. Morale there was buttressed by economic prosperity: 'a big town was more resilient under bombing than a small town, since it has a larger capacity for absorbing within itself a displaced population'. ${ }^{57}$ In neither town did Bernal and Zuckerman find 'any evidence of panic', although in Hull the situation was obscured by 'trekking' (travelling out of the city in the evening and returning again in the morning), which they interpreted not as a sign of low morale but as a rational response to the destructiveness of air raids "made possible by the availability of road transport' 58

A further study led by a physiologist, Dr C. W. E. Emmens, investigated four towns hit in the 'Baedeker raids' (Norwich, York, Canterbury, and Exeter), while Bootle, Clydebank, and Greenock were added to assess the effects on ports and centres of manufacture. ${ }^{59}$ The 'Baedeker raids' were on inland cathedral cities of no appreciable military importance and were reprisals for the RAF raid on Lübeck. ${ }^{60}$ Drawing on reports prepared by the Ministry of Information, stories in the local press, social survey material gathered from house-to-house inquiries, and damage reports, they compared absentee rates for a period of three weeks after raids with the percentage of houses destroyed, effective density of the attack, and casualties per thousand. The data, expressed graphically, showed consistent linear relationships. ${ }^{61}$ From these figures, Emmens concluded that:

The relation of absenteeism for personal reasons to the percentage of houses destroyed and to the casualties per thousand, and possibly the effective density of the attack should give the best indices on which to base conclusions as to the relative morale of the various towns. ${ }^{62}$

He also discovered that the amount of trekking and evacuation was correlated to the number of buildings destroyed.

Only Greenock did not fit this pattern. Absenteeism was twice the level that might be predicted from either the percentage of buildings destroyed or the effective density of the attack. Home Intelligence reports confirmed low morale in the town and suggested that it was related to poor emergency facilities and a feeling that the local authorities had lost their 'grip of the situation'.

\section{V1 and V2 Attacks}

The V1 campaign, beginning on the night of 12-13 June 1944, and the V2 rocket attacks from 8 September 1944, took place when most citizens believed that they had overcome the worst of the air raids. Much 'nervous strain', suggested O'Brien, was "involved in listening to the "buzz-bombs" or "doodlebugs", watching them and waiting for the engine to cut out'. ${ }^{63}$ Reports by the Ministry of Information

\footnotetext{
${ }^{57}$ Ibid., p. 2.

${ }^{58}$ S. Zuckerman, From Apes to Warlords (London, 1978), p. 143.

${ }^{59}$ PRO, HO199/456, Assessment of Air-Raid Morale from the Local Press, Home Intelligence, Social Survey and Damage Reports, 19 June 1943.

${ }^{60}$ PRO, HO199/98, Brief appreciation of recent attacks on Bath, Exeter, Norwich, and York, 4 June 1942, p. 1.

${ }^{61}$ PRO, HO199/456, Assessment of Air-Raid Morale, Table 1, p. 3.

${ }^{62}$ Ibid., p. 3.

${ }^{63}$ O’Brien, Civil Defence, p. 659.
} 
suggested that Londoners were seriously affected by the sudden and unexpected attacks coming so soon after D-Day:

The raids have completely swamped all other war news for the great majority of Londoners. ... Nervousness, anxiety, strain and weariness are widespread. Sleepless nights account for much of the increased jitteriness and lowering of morale. Some people can 'scarcely believe that the raids have only been going for ten days' ${ }^{64}$

The Ministry judged that Londoners' spirits were 'lower now than at any time during the last two years'. ${ }^{65}$ Early signs of a potential breakdown in public discipline included the circulation of wild rumours. Stories spread of the capital being reduced to 'a heap of rubble' and of Londoners, 'scared or actually panicking', crowding into railway stations to leave the city. ${ }^{66}$ The need to deny the enemy targeting information during the initial phase of the V1 attacks had led to much government censorship. The Ministry of Information challenged this tactic:

In view of the widespread rumours, it is thought that more details should be published. . . People in target areas, and elsewhere, are critical of official and press accounts which appear to tone down the raids and the damage they cause. People ask for 'less secrecy and more true information'. ${ }^{67}$

However, by the end of June 1944, there were signs that 'people are beginning to adjust themselves to the [V1] raids'. A growing number of citizens believed that 'the anxiety expressed is greater than the damage warrants'. Outside London and along the south coast, 'some alarm' was reported:

at the possibility that they may drop anywhere at any time. People's nerves are said not to be standing up to them so well after five years of war. The general view, however, is that the new weapon is a nuisance but not nearly as bad as the raids which people expected to start when invasion [D-Day] began. ${ }^{68}$

By comparison, the V2, a ballistic missile, arrived out of the blue with no warning. The absence of a practical defence against the weapon led to a fatalistic attitude, and consequently its psychological impact was lessened. The opening of the V2 offensive had been greeted by an official silence, while stories were circulated that the damage was caused by exploding gas mains. Inevitably, the truth leaked out and in November 1944, when most people had concluded that they were caused by rockets, the government broadcast a formal acknowledgement. By this time, it was considered that 'the absence of warnings and the official silence add[ed] to the apprehensions of the nervous'. ${ }^{69}$ Following this confirmation, Home Intelligence officers wrote of the V2: 'a considerable number, however, show little concern, some preferring rockets to flying bombs' ${ }^{70}$

\footnotetext{
${ }^{64}$ Ibid., p. 4.

${ }^{65}$ PRO, INF1/292, Weekly Report by Home Intelligence, No. 196, 6 July 1944, p. 1.

${ }^{66}$ PRO, HO199/410, Ministry of Information, Home Intelligence Report, 20-27 June 1944, p. 1.

${ }^{67}$ PRO, HO199/410, Ministry of Information Home Intelligence Report, 27 June 1944.

${ }^{68}$ Ibid., p. 5.

${ }^{69}$ PRO, INF1/292, Home Intelligence Report, No. 214, 9 November 1944, p. 3.

${ }^{70}$ Ibid., No. 215, 16 November 1944, p. 3.
} 


\section{Psychiatric Casualties among Civilians}

In 1942, in the aftermath of the Blitz, R. D. Gillespie wrote: 'one of the most striking things about the effects of the war on the civilian population has been the relative rarity of pathological mental disturbances among the civilians exposed to air-raids'. ${ }^{71}$ Indeed, in 1941, the clinic set up in London by Edward Glover and other psychoanalysts to treat those traumatized by air raids was forced to close because they had no patients. ${ }^{72}$ Responsible for a nationwide survey of the incidence of neuroses among the general population, C. P. Blacker wrote that 'it was a source of almost universal surprise that, throughout the aerial bombardments of the civilian population in 1940 and 1941, very few of these conditions materialised'. 73

Contemporary reports indicated that acute cases of fear, anxiety, and confusion were not uncommon in areas subjected to heavy bombing but that these rapidly recovered with psychiatric first aid: rest, sympathy, and suggestion. Stokes recorded that 134 civilians suffering from fright or anxiety seen in a London first-aid post were all able to return home within 24 hours and only six required further psychiatric treatment. ${ }^{74}$ Brown, a psychiatric registrar at Guy's Hospital, identified cases of 'acute emotional shock', typified by tremor, tachycardia, and conversion symptoms, and 'acute transient hysterical reactions', which presented in 'a limp semistuperose state, usually with a tremor'. Both categories recovered rapidly with minimal intervention. ${ }^{75}$

In 1941, Aubrey Lewis analysed an influential investigation into the nature of psychological disorders presenting to a suburban London general practitioner in Willesden between September 1940 and May 1941 and compared them with equivalent figures for $1937 .^{76}$ In addition, various London psychiatric out-patient clinics were surveyed, together with six general practitioners and three out-patient psychiatrists based in Merseyside, a region that had been subjected to heavy raids in 1941. Although Lewis discovered that the stress of war, including air raids, was responsible for 75 per cent of those individuals breaking down for the first time, these numbers were not significant. His general conclusion based on war pension data from London and Bristol was that 'after intensive raids there is a slight increase in the total amount of neurotic illness in the affected area, occurring chiefly in those who have been neurotically ill before' ${ }^{77}$

However, Lewis urged caution in the interpretation of these statistics. 'Figures for neurosis', he conceded:

\footnotetext{
${ }^{71}$ R. D. Gillespie, Psychological Effects of War on Citizen and Soldier (New York, 1942), p. 106.

${ }^{72}$ P. Roazen, Oedipus in Britain: Edward Glover and the Struggle over Klein (New York, 2000), pp. $144-5$.

${ }_{74}^{73}$ C. P. Blacker, Neurosis and the Mental Health Services (Oxford, 1946), p. 22.

${ }^{74}$ Stokes, 'War Strains', p. 216.

${ }^{75}$ F. Brown, 'Civilian Psychiatric Air-raid Casualties', Lancet, 1 (1941), 686-91.

${ }^{76}$ A. Lewis, 'Incidence of Neurosis in England under War Conditions', Lancet, 2 (1942), 175-83. See also, PRO, FD1/6580, A. Lewis, Report into the Incidence of Neurosis.

${ }_{77}^{7}$ Lewis, 'Incidence of Neurosis', p. 182. See also, J. Whitby, 'Neurosis in a London General Practice during the Second and Third Years of War', Proceedings of the Royal Society of Medicine, 36 (1942), 123-8.
} 
are difficult. Diagnosis is untrustworthy; a patient may appear at several clinics in turn . . [and] many neurotic patients, when they come to hospital, are not seen in the psychiatric department, but in the medical or specialist division with which their presenting symptom would appear to be concerned. ${ }^{78}$

Lewis believed that the full effect of war-related stress might be delayed and that 'the evil harvest may be reaped afterwards' when the Ministry of Pensions would be flooded by claims for compensation. ${ }^{79}$

The reservations expressed by Lewis were supported by a follow-up study of admissions to a first-aid post in an English city subjected to heavy bombing. The investigators interviewed 127 cases (76 per cent of the sample) 10 months after the raids. Of the 35 who had been buried for more than one hour, 66 per cent had developed neurotic symptoms and 40 per cent were sufficiently troubled to be absent from work. ${ }^{80}$ They concluded that severe personal experiences were likely to cause psychological disorders even in people with no history of vulnerability.

In an attempt to address what he believed were unrealistic and complacent attitudes about the incidence of 'nervous and shock response among the civilian population', Harrisson wrote to the British Medical Journal in April 1941. He and his team had observed individuals, who:

after a heavy bombardment, have left the next morning, found a billet with friends or relatives or strangers, and then caved in. In some cases they have simply taken to bed and stayed in bed for weeks at a time. They have not shown marked trembling or hysteria, but an extreme desire to retreat into sleep and into being looked after, as if chronically ill. ${ }^{81}$

These cases, Harrisson believed, rarely came to the attention of general practitioners or out-patient psychiatrists, but exercised 'a profound effect on the morale of many others'. Crichton-Miller and Clifford Allen responded unconvincingly that cases of stupor or extreme distress could be explained entirely by the physical effects of raids (blast-concussion, anoxaemia, and toxic absorption from a septic focus). ${ }^{82}$ In response, Harrisson stated that most of these individuals had not been directly affected by bombardment but had seen its effects nearby and assumed that it was their 'turn next'. People who had been bombed and survived did not seem to suffer in this way, believing that lightening would not strike twice. ${ }^{83} \mathrm{He}$ concluded that "no one who has spent any time objectively studying the "blitztowns" and getting right in among the mass of the people could shut their eyes . . . to the very considerable effect that continuous raiding has on people's nervous system' ${ }^{84}$

A post-war study of civilian responses to the dropping of atomic bombs on Hiroshima and Nagaski supported Lewis and Gillespie's interpretation rather than that of Harrisson. American investigators found 'no references to excited,

${ }^{78}$ A. Lewis, 'Mental Health in War-time', Public Health, 57 (1943), 27-30, p. 28.

${ }^{79}$ Ibid., p. 27.

${ }^{80}$ R. Fraser, I. M. Leslie, and D. Phelps, 'Psychiatric Effects of Severe Personal Experiences during Bombing', Proceedings of the Royal Society of Medicine, 36 (1942), 119-23.

${ }^{81}$ T. Harrisson, 'Obscure Nervous Effects of Air-raids', British Medical Journal, 1 (1941), 573.

${ }^{82}$ H. Crichton-Miller, 'Somatic Factors Conditioning Air-raid Reactions', Lancet, 2 (1941), 31-4.

${ }^{83}$ Harrisson, 'Obscure Nervous Effects', p. 832.

${ }^{84}$ Ibid. 
uncontrolled behaviour that could be characterised as overt "panic", ${ }^{85}$ Despite the destructive effect of the atom bomb, morale did not fall below that recorded in other Japanese cities. Although Janis concluded that there was no appreciable increase in the incidence of major mental illness, he suggested that psychosomatic symptoms, in particular associated with the gut, were frequently observed after heavy air attacks.

Recently, Shephard questioned the apparent absence of traumatic neurosis: 'photographs of people being pulled from the rubble and reports of conditions after some raids do make one wonder whether psychiatrists, having reflected the psycho-panic of 1938, were now affected by the "Britain can take it" mood of 1940-41'. ${ }^{86}$ Glover believed that pre-war hysteria about mass casualties was replaced by a new myth of universal resilience. A Coventry-based psychiatrist quoted by Lewis in May 1941 had written:

my general impression is that the number of neurotic disturbances is considerably higher than we realise, but that the cases just do not get treatment; that is not to say, however, that the majority of them do not make a spontaneous recovery. ${ }^{87}$

\section{Functional Somatic Disorders}

Although Lewis was unable to discover a significant increase in the number of civilians suffering from 'war neuroses' in the aftermath of air raids, there is evidence to suggest that functional somatic disorders may have risen appreciably. On an anecdotal level, reports suggested that patients presented with unexplained medical symptoms such as headache, fatigue, dyspepsia, joint, and muscle pain. Molesworth, a Home Security official, interviewed a panel doctor based in Filton, a northern Bristol suburb, who reported an increased incidence of indigestion cases, and estimated at least 15 per cent absenteeism after severe raiding. ${ }^{88}$ Glover argued that most civilians vulnerable to the stress of air raids tended to express their fears as bodily sensations and were either treated as cases of apparent organic illness or suffered without referral. ${ }^{89}$ Gastro-intestinal symptoms were often emphasized, which related to the epidemic of peptic ulcer that Britain then experienced. Contemporaries believed that stress was a causal factor, together with wartime dietary changes.

Although Brown agreed with Lewis's conclusion that 'definite psychoneuroses, induced by air-raids in patients who have previously shown no psychoneurotic traits are comparatively rare', he also observed functional somatic symptoms in patients with no history of mental illness. His anecdotal evidence suggested that 'a particularly horrible experience is needed to precipitate this reaction in a previously normal person'. ${ }^{90}$

\footnotetext{
${ }^{85}$ I. L. Janis, Air War and Emotional Stress, Psychological Studies of Bombing and Civilian Defence (New York, 1951), p. 38.

${ }^{86}$ B. Shephard, A War of Nerves (London, 2000), p. 178.

${ }^{87}$ Lewis, 'Incidence of Neurosis', p. 179.

${ }^{88}$ PRO, HO199/276, Bristol and Cardiff, Public Morale Report, p. 2.

${ }^{89}$ E. Glover, 'Notes on the Psychological Effects of War Conditions on the Civilian Population', International Journal of Psychoanalysis, 23 (1942), 17-37.

${ }^{90}$ Brown, 'Air-raid Casualties', p. 687.
} 


\section{Preventive Factors}

Factors that militated against a feeling of helplessness and gave people a sense of control, supported morale. The idea of an active defence against attacks lifted the spirits of those not directly involved in the conduct of the war. During the Blitz, for example, anti-aircraft batteries were fired when it was known that their chances of hitting night raiders were minimal and that the falling shrapnel was a danger to people and property. In July 1941, the Civil Defence Commissioner for the Southern region observed that 'the feeling that we are no longer on the defensive . . . has had not merely an encouraging effect but has induced some people . . to take the view that we are through the worst'. ${ }^{91}$ Involving the civil population in constructive activities also served to generate resilience. By spring 1941, as a result of air raids, rationing, war work, and civil defence, 'everyone', wrote Taylor, 'has some sense of participation in the work of the country', while 'the uncertain fear of the unknown has gone'. ${ }^{92}$ Indeed, by June of that year, 1.8 million citizens had joined either full- or part-time civil defence and police services, while 5 million were later engaged in the Fire Guard organization. ${ }^{93}$

It is difficult to judge the extent to which protective measures safeguarded morale. Reports from Finland suggested that those with a vulnerability to psychological stress were attracted to safe places: 'persons in raided areas would go and sit in shelters at times when no raid was in progress to recover from an attack of wind up'. ${ }^{94}$ However, only one significant example of a deep-shelter mentality has been identified in the UK. After a series of raids on Ramsgate late in 1940, several hundred people congregated in a tunnel shelter where they lived permanently, despite the absence of proper sanitation and schooling for their children. Morale was described as 'almost non-existent'. ${ }^{95}$ Fearing that these squatters would depress the spirit of the surrounding population, they were evicted.

Anecdotal reports suggested that morale was higher in those towns where the people believed that anti-aircraft defences were effective and shelter accommodation widely available and safe. This factor would explain the report of a regional intelligence officer based in Reading, who claimed in September 1940 that 'generally speaking, morale appears to be best in those places which have been heavily bombed'. ${ }^{96}$ After the 'tip and run' raids on southern coastal towns in 1942, there was widespread demand for Morrison shelters and a rapid up-take of them when they were delivered. Conversely, the combination of lack of preparation, inexperienced emergency services, and low morale was seen in Barrow in July 1940:

for the first 24 hours people were rather shaken. The Civil Defence services were not as effective as they might have been, and there had been a widespread idea that Cumberland was safe and was not likely to suffer appreciably from air bombing. ${ }^{97}$

${ }^{91}$ PRO, HO199/411, Morale Reports by Regional Commissioners, No. 6, 15 July 1941.

${ }_{93}$ PRO, INF1/292, Taylor, Home Morale, p. 7.

${ }_{93}$ O'Brien, Civil Defence, p. 605, Appendix X.

${ }^{94}$ PRO, HO199/410, Memorandum from the Intelligence Branch HSWR to regional intelligence correspondents, 20 May 1940.

${ }^{95}$ PRO, HO207/1101, Letter from E. J. Hodsoll, Inspector General of Civil Defence, 4 February 1941.

${ }^{96}$ PRO, INF1/264, Points from Regions, 29 September 1940.

${ }^{97}$ PRO, HO199/410, Monthly Report, Region 10, July 1940. 


\section{Conclusions}

In general, the British people responded with fortitude to the aerial assaults of the Second World War, resigning themselves to the dangers while engaging in the war effort. Morale fluctuated, but never broke. Although some individuals lost selfcontrol during raids, large-scale panic was a rare event and occurred in defined circumstances, such as the Bethnal Green Tube station disaster. ${ }^{98}$ Mental illness did not increase significantly, although a question has been raised about the incidence of psychosomatic disorders, such as effort syndrome and non-ulcer dyspepsia. Only a detailed analysis of hospital admission and out-patient records will resolve this issue.

Contemporaries struggled to explain why the predicted epidemic of air-raid neurosis failed to appear. If so many soldiers had succumbed to shell shock during the First World War why, then, did civilians behave so differently when exposed to the dangers of bombing? First, casualty rates in the trenches were far higher than in cities subjected to air attack. Secondly, civilians had less to gain by being hospitalized. For a soldier it resulted in a rapid transfer from danger and possible transfer to a non-combatant or base role. Some civilians, Brown recorded, 'ask, during recovery, to be sent to a quiet hospital, away from the anti-aircraft barrage. This is impossible ... It is even possible that recovery while the patient is in a noisy neighbourhood serves to desensitise him to noise. ${ }^{99}$ As Vernon observed, the civilian was not:

tempted to think that it would be an advantage to be sick or wounded, and he is usually already in, or close to, his own home. The importance of sentiments centred around the home in preserving mental stability is further indicated by the tendency towards deterioration . . . among those whose homes are destroyed. ${ }^{100}$

Contemporaries established an association between damage to homes and levels of resilience. As a result, larger cities were better able to cope than small ones. 'Plymouth or Coventry', observed Lewis in 1942, 'more unified, small and concentrated, can be so devastated that every citizen is affected, and the interference with essential services - food, warmth, light, water-serves to intensify depressive and other neurotic reactions' 101 'I know from personal experience', wrote Harrisson, 'that it is ten times more unpleasant to be blitzed in a place the size of Coventry or Bristol, where every bomb is personal and every piece of damage is a disaster to one's own town, instead of the great agglomeration of town which is called London.' 102

It seems that weapons may have varied considerably in their psychological effect. ${ }^{103}$ The quality of evidence available to planners had improved significantly by mid-

\footnotetext{
${ }^{98}$ L. R. Dunne, Report on the Inquiry into the Accident at Bethnal Green Tube Station Shelter on 3 March 1943 (London, 1945).

99 Brown, 'Air-raid Casualties', p. 687.

${ }^{100}$ Vernon, 'Psychological Effects', p. 475.

${ }^{101}$ Lewis, 'Incidence of Neurosis', p. 182.

${ }^{102}$ Harrisson, 'Obscure Nervous Effects', p. 832.

${ }^{103}$ B. Durodié and S. Wessely, 'Resilience or Panic? The Public and Terrorist Attack', Lancet, 360 (2002), 1901-2, p. 1901.
} 
1943. Recognizing the amateurish and anecdotal character of much information gathered at the beginning of the war and the need to base policy on reliable data, the government instructed the Research and Experiments Department of the Ministry of Home Security to conduct well-designed studies into the effects of air-raids. For example, Dr Emmens and his team investigated: numbers of casualties (killed and seriously injured), density of attack (tons of bombs per square mile), percentage of buildings destroyed, percentage of housing demolished, average number of working days lost over the following 17 days and numbers either evacuating or trekking, while Home Intelligence reports of the Ministry of Information were analysed and local newspapers assessed to measure the amount and content of space devoted to air-raid issues. Towns that they studied had been selected to represent different categories of economic and social function. Equally, the research supervised by Aubrey Lewis into psychiatric admissions (comparing 1940-41 with pre-war 1937) was conducted with due regard for problems of evidence and its representative character. Although the findings of Lewis and others were published in medical journals, the work of the Research and Experiments Department was considered helpful to the enemy in determining the effectiveness of aerial attacks and its reports were classified as 'secret'. The V1 flying bomb appeared to have been more feared than conventional air raids, although the latter caused more destruction. However, there is evidence to suggest that this initial psychological effect was not long-lived. Panic observed in British troops after the first German gas attack of 1915 was not repeated. The publication of technical details about the V1, and the introduction of increasingly effective counter-measures, conveyed to the public the conviction that the weapon was understood and could be defeated.

Indications of falling morale were rumour and some unofficial evacuation. Such stories allowed people to express fears that they were reluctant to state openly, and could serve as a safety valve. Yet, if such stories flourished and caught the popular imagination, it could undermine resolve. Spontaneous evacuation after the heavy raids on Belfast was described by some as close to panic, although regular nightly 'trekking' into the surrounding countryside or suburbs after heavy raids was, for many, a rational decision to avoid danger. In the event, it seems that civilians proved to be far more resilient in the face of war's technological advances than planners had predicted. It may well be that this was because they underestimated their adaptability and resourcefulness, but also because the length and scale of the conflict had involved so many in constructive participant roles. 